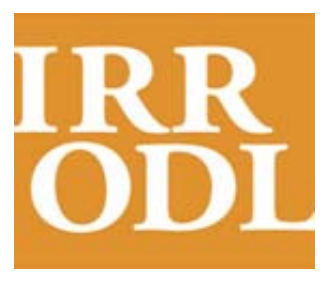

International

Review of

Research in Open

and Distance

Learning

Vol. 12.2

February - 2011

\section{Universal Instructional Design Principles for Mobile Learning}

\section{Tanya Elias}

Athabasca University, Canada

\begin{abstract}
The report extends a previous analysis of universal instructional design principles in distance education, by applying them to the design of mobile learning. Eight principles with particular relevance for distance education are selected, and their recommendations are discussed in relation to the design of educational materials for a range of mobile devices. The problems and opportunities of mobile learning are discussed, and the need for educators to focus on its content design issues rather than on searching for the next new technology.
\end{abstract}

Keywords: Universal instructional design principles; mobile learning 


\section{Introduction}

In a previous article in this series, the current author discussed the value of Universal Instructional Design (UID) principles for use with the learning management system, Moodle. The current article extends the discussion by discussing the application of UID in mobile learning (mlearning). M-learning has been championed as "a personal, unobtrusive, spontaneous, 'anytime, anywhere' way to learn and to access educational tools and material that enlarges access to education for all” (Kukulska-Hulme \& Traxler, 2005, p.1). It also been described as having the potential to "reach people who live in remote locations where there are no schools, teachers, or libraries,” (Ally, 2009, p. 2). This ability to reach new audiences in new places is particularly relevant in the developing world where mobile cellular penetration has more than doubled since 2005 and the adoption of mobile devices has outpaced the use of personal computers and landline Internet access (ITU, 2010). Thus, mobile devices are rapidly becoming the key to making information "universally accessible" (Wellman, 2007). In order to realise its potential, effective methods for offering high-quality and accessible m-learning are required.

Although a single definition of m-learning remains elusive, Traxler (2009) has stated:

Mobile learning exploits both handheld computers and mobile telephones and other devices that draw on the same set of functionalities. Mobile learning using handheld computers is obviously relatively immature in terms of both its technologies and its pedagogies, but is developing rapidly. It draws on the theory and practice of pedagogies used in technology enhanced learning and others used in the classroom and the community. (p.11-12)

To date, m-learning research in both the developed and developing world has focused on the use of handheld computers and smartphones (Kukulska-Hulme \& Traxler, 2005; Ally, 2009). In contrast, little research has concentrated on m-learning for simpler devices and/or those capable of running on limited networks (Trifonova \& Ronchetti, 2003). After a successful pilot using simply featured phones, Gregson \& Jordaan (2009) nonetheless referred to "the potential uses of the more recent smartphone and 3G handsets for supporting a broader range of academic activity within education in Africa” (p.225). Similarly, Ford \& Leinonen (2009) have identified

a desperate need for a new approach...particularly in the developing world environment. The model needs to take into account issues of usability, accessibility, and affordability, while ensuring that appropriate pedagogical models are adhered to... (p.198)

Thus, m-learning has much in common with traditional forms of face-to-face and online learning with respect both to its pedagogy and its use of technology. The current paper suggests that UID 
principles developed for other forms of learning can also be helpful in designing inclusive mlearning applications accessible to the largest possible audience from the simplest of devices.

\section{The Challenges and Opportunities of M-Learning}

M-learning design presents unique challenges.

1. Device variability. Nielson (2009) identified three categories of handheld mobile devices: feature phones with tiny screens and numeric keypads; smartphones that include an A-Z keypad and a mid-sized screen; and touch phones featuring a device-sized screen and activated by touch. Despite recent market excitement about the potential of higher-end smartphones and touch phones, feature phones continue to represent an estimated $85 \%$ of the mobile market. The significant challenges of m-learning are partly due to this diversity. As Stead (2010) has explained,

There is no single solution to push richly interactive mobile content onto every possible phone. Rather, there is a spectrum of possible solutions: On one side, going for the richest possible interactivities....and on the other side going for the widest possible phone coverage (para.3).

In many m-learning pilot projects, this challenge has been overcome by distributing to learners a specific mobile device and designing for that device. Students, however, generally want to learn on their own mobile devices (Bradley et al., 2010). Moreover, Herrington and Herrington (2009) point out that "using a learner's own device ensures that many of the features of the devices are well known and practiced" (p.136).

2. Slow download speed and limited Internet access. Despite advances in the delivery of mobile cellular broadband in North America and Europe, download speeds on mobile devices continue to present problems. These are compounded in regions of the world where highspeed broadband access is expensive and/or completely unavailable (ITU, 2010). To this point, most m-learning pilot projects have provided free access to the highest available level of mobile Internet access, although this approach is not in tune with the realities facing a large proportion of users, particularly in the developing world.

3. Small screen sizes with poor resolution, colour, and contrast. On hardware designed to fit in a pocket, small screen size continues to be a defining feature of handheld mobile devices. A typical screen size is $8-12$ centimetres long and 6-8 centimetres wide with the presentation usually being in portrait mode but sometimes in landscape. Resolutions vary and may or may not involve back-, front- or side-lit images with colour (JISC, 2010). Neilson (2009) estimated that the average success rate for accessing Web sites from feature phones was only $38 \%$. Smartphones and touch phones fared moderately better with success rates of 55 and $75 \%$ respectively. 
4. Awkward text input. Regardless of the device being used, inputting text data into small devices also presents challenges for the user. Inputting information into a device using a numeric (0-9) keypad on a feature phone continues to be tedious and time consuming. Again, the more sophisticated the device, the better its input capabilities.

5. Limited memory. Handheld phones have limited internal information storage capacity or memory. Extra random access memory (RAM) for the storage of programs and files may be added to devices from external memory sticks or cards (JISC, 2010), although these cannot be inserted into all handheld devices. Moreover, Kukulska-Hulme and Traxler (2005) pointed out that it takes slightly longer to retrieve data from external memory by comparison with internal memory - a fact that still applies five years later. In contrast, read-only memory (ROM), which runs the device operating system, cannot usually be increased (JISC, 2010).

But m-learning design also presents a distinctive set of opportunities.

1. Relatively inexpensive m-learning opportunities. Although cost remains a barrier to mlearning in many parts of the world, handheld mobile devices and cellular services are significantly less expensive than PCs and laptops with fixed Internet service (ITU, 2010). During a pilot project in Africa, Ford and Leinonen (2009) found that if "the phones used were basic models and only needed to support the ability to send an SMS, the cost factor for the handset was small” (p.225). Moreover, the size and inherent portability of the devices facilitates information sharing as a method of lowering access costs more easily. In fact, Kreutzer (2009) found that for many young South Africans, mobile phone handsets are quickly becoming the Internet platform and multimedia device of choice. Moreover, he noted that not owning a phone "does not seem to create a 'mobile divide' or automatically lead to exclusion from the possibilities of mobile Internet access” (Kreutzer, 2009, p.ii).

While the hardware devices themselves may be relatively inexpensive, network access can present additional challenges. Ramos et al. (2006) found in the Philippines that $81 \%$ of those surveyed would be willing to set aside a portion of their prepaid cell-phone credits for learning. Although cost will continue to present a barrier to m-learning for some populations, the entry point for this type of learning is potentially much lower than for forms of online learning.

2. Multimedia content delivery and creation options. Mobile devices allow sound, text, pictures, and video files to be downloaded to the device and uploaded from the device. In addition, they feature built-in speakers and, almost always, cameras. Ford and Leinonen (2009) used a mobile audio-wikipedia that supported increased access to information in a region "where the access to information, both paper-based and electronic, is limited" and built on "the strong African oral tradition" (p. 210).

3. Continuous and situated learning support. Mobile devices allow ongoing learning to occur in multiple locations, including the potential to offer scaffolded support (Saye \& Brush, 2002) to learners undertaking authentic tasks. Using these devices in a way that maximises these 
learning benefits has the potential to offer educational opportunities that are both more inclusive and of higher quality. As Nyíri (2002) has explained:

Mobile communication is enhanced everyday communication; and just as our everyday conversation is indifferent towards disciplinary boundaries, so, too, is m-learning. Situation dependent knowledge, the knowledge at which m-learning aims, by its nature transcends disciplines; its organising principles arise from practical tasks; its contents are multisensorial; its elements are linked to each other not just by texts, but also by diagrams, pictures, and maps” (p. 124).

\section{UID Recommendations for M-Learning}

UID principles have been developed to build flexibility of use into both the instructional design and operating systems of educational materials so that they will be appropriate to the widest range of students (Connell et al., 1997; Scott et al., 2002; Burgstahler, 2007). Elias (2010) extracted from these eight UID principles particularly useful in distance education (DE):

1. equitable use,

2. flexible use,

3. simple and intuitive,

4. perceptible information,

5. tolerance for error,

6. low physical and technical effort,

7. community of learners and support, and

8. instructional climate.

Although not specifically developed for m-learning environments, these are equally relevant to them. The relevance of almost all of these principles for designing inclusive online learning is further increased when designing inclusive m-learning. Table 1 compares the most relevant recommendations arising from UID principles for online learning with a series of additional recommendations for m-learning. 
Table 1

UID Recommendations for Inclusive M-Learning

\begin{tabular}{|c|c|c|}
\hline UID Principles & Online DE recommendations & M-learning recommendations \\
\hline 1. Equitable use & $\begin{array}{l}\text { - put content online } \\
\text { - provide translation }\end{array}$ & $\begin{array}{l}\text { - deliver content in the simplest } \\
\text { possible format } \\
\text { - Use cloud-computing file storage } \\
\text { and sharing sites }\end{array}$ \\
\hline 2. Flexible use & $\begin{array}{l}\text { - present content and accept } \\
\text { assignments in multiple formats } \\
\text { - offer choice and additional } \\
\text { information }\end{array}$ & $\begin{array}{l}\text { - Package content in small chunks } \\
\text { - consider unconventional } \\
\text { assignment options } \\
\text { - Leave it to learners to illustrate } \\
\text { and } \\
\text { animate courses }\end{array}$ \\
\hline $\begin{array}{l}\text { 3. Simple and } \\
\text { intuitive }\end{array}$ & $\begin{array}{l}\text { - simplify interface } \\
\text { - offer offline and text-only options }\end{array}$ & $\begin{array}{l}\text { - keep code simple } \\
\text { - use open-source software }\end{array}$ \\
\hline $\begin{array}{l}\text { 4. Perceptible } \\
\text { information }\end{array}$ & $\begin{array}{l}\text { - add captions, descriptors and } \\
\text { transcriptions }\end{array}$ & \\
\hline $\begin{array}{l}\text { 5. Tolerance for } \\
\text { error }\end{array}$ & $\begin{array}{l}\text { - allow students to edit posts } \\
\text { - issue warnings using sound and } \\
\text { text }\end{array}$ & $\begin{array}{l}\text { - scaffold and support situated } \\
\text { learning methods }\end{array}$ \\
\hline $\begin{array}{l}\text { 6. Low physical } \\
\text { and technical } \\
\text { effort }\end{array}$ & $\begin{array}{l}\text { - incorporate assistive technologies } \\
\text { - consider issues of physical effort } \\
\text { - check browser capabilities }\end{array}$ & $\begin{array}{l}\text { - use available SMS readers and } \\
\text { other mobile-specific assistive } \\
\text { technologies }\end{array}$ \\
\hline $\begin{array}{l}\text { 7. Community of } \\
\text { learners and }\end{array}$ & - include study groups and tools & - encourage multiple methods of \\
\hline
\end{tabular}




\begin{tabular}{|l|l|l|}
\hline support & - easy-to-find links to support & communication \\
& Services & $\begin{array}{l}\text { - group learners according to } \\
\text { technological access and/or } \\
\text { preferences }\end{array}$ \\
\hline $\begin{array}{l}\text { 8. Instructional } \\
\text { climate }\end{array}$ & - make contact and stay involved & $\begin{array}{l}\text { - push regular reminders, quizzes } \\
\text { and questions to students } \\
\end{array}$ \\
\hline
\end{tabular}

1. Equitable use. Course content should be accessible to people with diverse abilities and in diverse locations. With respect to m-learning, this involves developing content and assignments that can be accessed on a wide variety of devices. As a result, to develop accessible m-learning one ought to do the following.

- Deliver content in the simplest possible formats. Short Messaging Systems (SMS), or texting technology is cheap and given its high levels of penetration is almost universally accessible. Mitchell (2002) indentified "simplicity of use, relatively low cost and the asynchronous nature of SMS, which gives people time to reflect before responding to a message [as] undoubtedly part of its phenomenal success (Mitchell, 2002). Issham et al. (2010) found a high level of acceptance of SMS-learning as "safe, easy, effective and usable to help them in their studies” (p.14). JISC (2010) has described SMS as a classic example of an "m-learning accessibility model. Although it poses all kinds of physical and usability barriers to disabled learners the motivation for using it is sufficiently high that there are few who do not actively manage to master it to some extent.”

There are numerous ways to address these accessibility issues (see item 6). Developing primary content using SMS can be a simple yet elegant way of ensuring that diverse learners have access to required materials. Wijayanto (2006), for example, designed an SMS-based public education system to both inform the public and to gather information regarding avian 'flu.

- Use cloud-computing file storage and sharing sites. Given the small storage capacity of most handheld devices, file-storage sites may offer users the same level of flexibility in completing assignments as is available to those with more sophisticated hardware and/or connectivity. A study at a South African high school, for example, indicated that only $33 \%$ of students had access to phones with substantial internal and flash-card memory. This led "to the regular deletion of older content in order to make room for new material" (Kreutzer, 2009, p.69). Using external storage sites would enable these students to save more information, develop more complex projects, and engage more fully in learning. 
2. Flexible use. According to this UID principle, course design should accommodate a wide range of individual abilities, preferences, schedules, levels of connectivity, and choices in methods of use. As with other forms of inclusive learning, inclusive m-learning should offer choice in how materials are used. SMS-based m-learning offers fast transmission of information to students who are bound to neither a computer nor a classroom. Whereas other types of education go to great lengths to simulate real-world situations and to bring the outside world into the classroom through the use case studies, role-plays, photographs, videos, and so on, m-learning has the potential to bring the learning out of the classroom to remote students. SMS-based solutions may often be more than adequate for this but will require significant adjustments.

- Package content in small bits. Clearly, the use of an SMS system, with its 160 character limit, forces content to be brief. The length of resources needs to be considered in taking download speed and costs into account. Bradley et al. (2009) divided materials into "manageable learning chunks" (p. 281) and separated text over several screens. Although, seeking out such ways to package content may present challenges, it may also have pedagogical advantages for all learners owing to the elimination of dead wood information that is not essential for attaining a learning goal (Ragan \& Smith, 2005).

- Consider unconventional assignment options. Suggesting and accepting unconventional assignments allows learners to look for unique ways to use the multimedia features of their devices and to compensate for the hardware's shortcomings. In the South African project, for example, the inclusion of multimedia options led to audiocasts that "were passionate and uninhibited and included spontaneous harmonizing of songs, including rap songs” (Ford \& Leinonen, 2010, p.207).

- Leave it to learners to illustrate and animate courses. In contrast to traditional teaching environments where instructors are predominantly responsible for incorporating the real world into the classroom, mobile devices have the potential to transfer that responsibility to the learners themselves. Using phones with cameras/video capabilities, students can capture their own material and instantaneously it them to other students and instructors and/or upload it for storage. Discussion could then revolve around real-world examples defined by the learners.

3. Simple and intuitive. Unnecessary complexity should be eliminated and course design rendered simple and intuitive. As already mentioned, the simplest mobile delivery system is currently SMS. To post and share their own multimedia content, however, learners must access multimedia messaging systems (MMS), email, and/or a mobile Internet service. When developing and/or selecting existing sites for use, the following guidelines are useful:

- Keep learners' interfaces simple. It should be ensured that they contain only information that can fit comfortably on the smallest of screens. 
- Keep code simple. Sites that use HTML provide a simple and relatively accessible content delivery system with useful features including the ability to link between pages and sites. Use of simple coding minimises files sizes, increases download speeds, and is better supported on feature phones that may not give good support for cascading style sheets and other advanced programming functions.

- Use open sites and software. Open sites and software help to ensure that learners have ongoing access to resources and lower costs. Ford and Leinonen (2009) state that this facility "stimulates the local IT sector in a country, which is crucial in developing countries to ensure full participation in the information society" and "allows software to be customized to local conditions by the communities themselves” (p. 199). The use of open-source products, therefore, advances not only simple access to content but also (relatively) simple access to m-learning development tools.

4. Perceptible information. With respect to this UID principle, one of the recommendations for online learning is to add captions, descriptors, and transcriptions (Elias, 2010). SMS-based materials would not require these added features. Instructors may encourage learners to include them, however, when their assignments include media elements. Nevertheless, it is likely that not all student-posted materials will be accessible to all users. Strategies are suggested to mitigate these issues (see item 7).

5. Tolerance for error. UID principles also minimise hazards and adverse consequences of errors in software operation by designing learning environments with a tolerance for error. While m-learning errors are likely to be similar to those encountered in traditional online learning, an additional m-learning-specific recommendation may be identified:

- Scaffold and support situated learning. M-learning is uniquely positioned to support situated learning (Lave \& Wenger, 1990). In many settings it may be valuable for learners to be able to access learning materials via their mobile device while performing a task or skill. In these cases, job performance aids included in the learning package may reduce learner errors by providing just-in-time training and support as and when required. Providing simple, short text-based support in rich learning contexts has an excellent educational potential.

6. Low physical and technical effort. As with online learning, m-learning should be developed requiring a low technical and physical effort. The physical effort related to inputting text into devices is therefore a primary concern. Clearly answering test essay questions on such a device would be tedious if not impossible. As indicated in relation to SMS usage, the difficulties associated with inputting text data into mobile devices poses the challenge of developing new, authentic, and inclusive forms of assessment. In addition, inclusive mlearning should seek out opportunities to do the following: 
- Use available SMS reader software and other mobile-specific assistive technologies. Several SMS readers are freely available with potential value to learners who are visually impaired, who are auditory learners, or who are studying while driving. A clip-on magnifier can easily be attached to increase font size and visibility (JISC, 2010). An external device to convert SMS to Braille was developed in the Philippines (Estopace, 2004) but may not be commercially available today.

7. Community of learners and support. As in other forms of learning, community support for learning should be facilitated through the development of groups and support from appropriate tools.

- Encourage multiple methods of communication. Learners should be encouraged to experiment with the standard communication options of mobile devices (SMS, email, instant messaging, and voice communication) in developing relationships with and support for one another. Using these features, they can scaffold one another (Saye \& Brush, 2002) in working collaboratively to theorise and solve ill-structured realworld problems.

- Group learners according to technological access and/or preferences. In the development of inclusive m-learning, it is likely that diverse learners will have differing levels of access to and interest in multimedia technologies. It may be preferable to combine learners into groups along these lines. For example, if some learners use only SMS text in a course, they may prefer to work together rather than with learners who have access to MMS and/or Internet. Grouping students in such a way may reduce their sense of "missing out” on specific delivery features.

8. Instructional climate. This UID principle focuses on the instructor's impact in course delivery as opposed to course design. M-learning instructors can send regular SMS messages to interact with learners in various ways. For example, they can do the following:

- Push regular reminders, requests, quizzes, and questions. Instructors can easily generate and send reminders about assignments, weekly expectations, and interactive quizzes using SMS (Ramos et al., 2010). Such systems can be effective in generating discussion and in inviting various forms of student feedback.

- Pull in learner-generated content. As instructors push their content out, they can continuously pull in student-generated content in various forms (SMS and MMS, audio files, pictures, videos, etc.). Regardless of the hardware, the key is for the instructor to foster an inclusive environment that supports learning through sharing and collaboration in which the contributions of all learners are valued. 


\section{Conclusions}

Inclusive and accessible education should aspire to include all learners. Mobile learning appears to have the potential to do that. SMS and MMS technologies offer excellent opportunities to open up education to many who have long been excluded from it. This effort, however, will involve the development of creative techniques for relatively simple technologies and the design of universally accessible educational materials for them. The challenge will force educators to rethink their current approaches to teaching. They should not look exclusively for the next great technological advance but rather should focus on the accessible design of materials using tools that are currently available. Intensive research is needed to consider the ways in which appropriate technologies and solid pedagogical approaches can remove the barriers to educational diversity. The principles of universal instructional design will play a valuable role in this process. 


\section{References}

Ally, M. (2009). Mobile learning: Transforming the delivery of education and training. Edmonton, AB: Athabasca University Press.

Burgstahler, S. (2007). Universal design of instruction: Definition, principles, and examples. University of Washington. Retrieved from http://www.washington.edu/doit/Brochures/Academics/instruction.html

Connell, B., Jones, M., Mace, R., Mueller, J., Mullick, A., Ostroff, E., Sanford, J., Steinfeld, E., Story, M., \& Vanderheiden, G. (1997). The principles of universal design. Raleigh, NC: Center for Universal Design, North Carolina State University.

Bradley, C., Haynes, R., Cook, J., Boyle, T., \& Smith, C. (2009). Design and development of multimedia learning objects for mobile phones. In M. Ally (Ed.) Mobile learning: Transforming the delivery of education and training (pp. 157-182). Edmonton, AB: Athabasca University Press.

Elias, T. (2010). Universal instructional design principles for Moodle. International Review of Research in Open and Distance Learning 11(2). Retrieved from http://www.irrodl.org/index.php/irrodl/article/view/869

Estopace, E. (2004). Text messaging for the blind: Proudly Filipino. Philippine Headline News Online. Retrieved from http://www.newsflash.org/2004/02/si/si001957.htm

Ford, M., \& Leinonen , T. (2009). MobilED - mobile tools and services platform for formal and informal learning. In M. Ally (Ed.) Mobile learning: Transforming the delivery of education and training (pp. 195-214). Edmonton, AB: Athabasca University Press.

Gregson, J., \& Jordaan, D. (2009). Exploring the challenges and opportunities of m-learning within an international distance education programme. In M. Ally (Ed.) Mobile learning: Transforming the delivery of education and training (pp. 215-246). Edmonton, AB: Athabasca University Press.

Herrington, A, Herrington, J., \& Mantei, J. (2009). Design principles for mobile learning. In J. Herrington, A. Herrington, J. Mantei, I. Olney \& B. Ferry (Eds.), New technologies, new pedagogies: Mobile learning in higher education. University of Wollongong. Retrieved from http://ro.uow.edu.au/edupapers/88/

Lave, J., \& Wenger, E. (1990). Situated learning: Legitimate peripheral participation. Cambridge: Cambridge University Press.

International Telecommunications Union (2010). Measuring the information society 2010. Geneva, Switzerland: ITU. 
Issham, I., Siti, S. Johari, M., \& Rozhan, I. (2010). Acceptance on mobile learning via SMS: a Rasch model analysis. International Journal of Interactive Mobile Technologies 4(2). Retrieved from http://www.scribd.com/doc/29729105/Acceptance-on-Mobile-Learningvia-SMS-A-Rasch-Model-Analysis

Joint Information Systems Committee (JISC) (2010). JISC TechDis advice and guidance on mlearning. Retrieved from http://www.techdis.ac.uk/index.php?p=9_5

Kreutzer, T. (2009). Generation mobile: Online and digital media usage on mobile phones among low-income urban youth in South Africa. Retrieved from http://tinokreutzer.org/mobile/

Kukulska-Hulme, A., \& Traxler, J. (2005). Mobile learning in developing countries. Vancouver: Commonwealth of Learning. Retrieved from http://www.col.org/resources/publications/trainingresources/knowledge/Pages/mobileLea rning.aspx

Mitchell, A. (2002). Translating mobile technologies into learning technologies: creating a microportal layer for the m-learning project. Online Educa Berlin (28 November). Retrieved from http://www.mlearning.org/docs/Online\%20Educa\%20paper\%2028\%20Nov\%2002.rtf

Neilsen, J. (July 20, 2009). Mobile usability [blog post]. Retrieved from http://www.useit.com/alertbox/mobile-usability.html

Nyíri, K. (2002). Towards a philosophy of m-learning. Proceedings of Wireless \& Mobile Technologies in Education. from http://academic.research.microsoft.com/Paper/4325835.aspx

Ramos, A., Trinoña, J., \& Lambert, D. (2006). Viability of mobile SMS technologies for nonformal distance education. In J. Baggaley (Ed.), Information and communication technology for social development (pp. 69-79). Jakarta: ASEAN Foundation.

Ramos, A., \& Triñona, J. (2010). Mobile technology in non-formal distance education. In J. Baggaley \& T. Belawati (Eds.), Distance education technologies in Asia. New Delhi: Sage India.

Saye, J., \& Brush, T. (2002). Scaffolding critical reasoning about history and social issues in multimedia-supported learning environments. Educational Technology Research \& Development 50(3), 77-96.

Scott, S., McGuire, J., \& Shaw, S. (2003). Universal design for instruction: A new paradigm for adult instruction in postsecondary education. Remedial and Special Education 24(6), 369-379. 
Smith, P., \& Ragan, T. (2005). Instructional design ( $3^{\text {rd }}$ ed.). Hoboken, NJ: Wiley.

Stead, G. (2010). Moblearn: The mobile generation is learning. Retrieved from http://moblearn.blogspot.com/2010/06/can-my-m-learning-course-run-same-on.html

Traxler, J. (2009). Learning in a mobile age. International Journal of Mobile and Blended Learning 1(1), 1-12.

Trifonova, A., \& Ronchetti, M. (2003). Where is mobile learning going?. In A. Rossett (Ed.), Proceedings of World Conference on E-Learning in Corporate, Government, Healthcare, and Higher Education, pp. 1794-1801. Chesapeake, VA: AACE. Retrieved from http://www.editlib.org/p/12226

Wijayanto, B. (2006). Using SMS methods to combat avian flu. In J. Baggaley (Ed.) Information and communication technology for social development (pp. 81-92). Jakarta: ASEAN Foundation.

Wellman, S. (2007). Google lays out its mobile user experience strategy (11 April). Retrieved from

http://www.informationweek.com/blog/main/archives/2007/04/google_lays_out.html

\section{Athabasca University $\mathbf{A}$}

